\title{
Forest Tenure and Sustainable Forest Management: Drawing Lessons from the Literature
}

\author{
Gordon Kofi Sarfo-Adu \\ Corporate Planning Manager \\ Department of Corporate Planning, Monitoring and Evaluation \\ Forestry Commission, Ghana
}

Tel: 233-244-286-127/233-208-420-472

E-mail: gsarfoadu.hq@fcghana.org/gsarfoadu@gmail.com

Received: July 10, 2018 Accepted: February 10, 2021 Published: February 25, 2021

doi:10.5296/emsd.v10i2.18345

URL: https://doi.org/10.5296/emsd.v10i2.18345

\begin{abstract}
The quest to foster sustainable forest management (SFM) in the era of sustainable development goals has reignited the debate on forest tenure concerns. Land and forest tenure insecurity has remained a major underlying cause of deforestation in Africa, which suggests that addressing tenure issues could effectively foster sustainable forest management. Adopting theoretical literature and drawing lessons from related empirical works, this study examines the role of land and forest tenure in sustainable forest management drive. Among other things, the study discusses how land tenure promotes or inhibits sustainable forest practices. The study outlines how frustrating tenure regimes deprive the community of the needed benefits and subsequent untoward behaviour unleashed on forests. The study concludes that the idea of tenure rights and tenure security has implications on sustainable forest management and admonishes a robust tenure regime that upholds local 'people's access to and usage of forest resources without sinister machinations and subjugation of local people. The study contends that determined rights and their long-term security remain crucial in attracting the tenure holders to make a strenuous investment in SFM since investments in forestry usually are made for the long term. Among other things, the study recommends for clarity and long-term security of ownership and tenure rights regarding forest products; a need to promote capacity-building for administrators and rights holders to adopt a sustainable mindset in their exploitation of timber products; and a need to foster stakeholder participation.
\end{abstract}

Keywords: Tenure, Sustainability, Forestry, Participation, Empowerment, Local community 


\section{Introduction}

The past three decades have primarily been associated with a proliferation of forest rights devolution flowing to forest fringe communities in Asia, Africa, and Latin America (Larson et al., 2010). This trend is mostly propelled by structural weaknesses associated with centralized state management of forest resources with regards to effectiveness and equity, and increasing recognition of the rights of forest fringe communities and 'people's empowerment (Larson et al., 2010). This has become even crucial in the wake of the sustainable development era, which argues for socioeconomic advancement of people and recognition of their rights (Campese et al., 2009). Many forests in developing countries had historically been managed and protected by local people through their leaders and used by communities for their livelihoods. However, government intervention sought to centralize and alienate communities in the usage and management of most forests (Dixon \& Sherman, 1991; Fay \& Michon, 2003). Conservation scholars have noted various cases where forest fringe communities whose livelihoods have become exacerbated due to government policies of exclusively taking over forest management such as forest classification regimes that proscribe community access and use (e.g. Peluso, 1992); or the introduction of large private miners or timber companies through government-authorized concessions (Anaya \& Grossman, 2002). What is perhaps mostly recorded has been the phenomenon of evicting local people from their place or imposition of severe austere restrictions on livelihood activities in and around protected areas or those designated as parks (e.g. Adams \& Hutton, 2007).

Critical concerns for centralization had been the designation of lands for royal and elite hunting grounds; the economic value of trees; a commitment to professional or fortress state management; a quest to maximize future timber supplies; and protection of environmental services. Despite the concerns above, a key observation in forest tenure is that since the 1980s various countries in Asia, Africa and Latin America began to introduce major structural and institutional reforms that attempted to offer new tenure rights to forest fringe communities (Sunderlin et al., 2008). These tenure reforms have been introduced mainly as a result of increasing deforestation that was noted with exclusive government management of forests as well as the quest to reduce state budget on conservation and also to garner legitimacy for government policies. Besides these top-down drivers, there have also been other 'bottom-'up' initiatives and pressures from local communities who seek opportunities demanding the regain of their rights and to forests through customary rights which had been appropriated by the State. Consequently, Sunderlin et al. (2008) argue that data from the developing world suggest some $27 \%$ of forests have been designated for management by local populations, with rights to at least 200 million hectares transferred or recognized since 1985. These are to be managed, protected and used by local people who when poorly regulated, could also exacerbate deforestation phenomenon. In most parts of Africa, the forest is a common pool resource exhibiting a mixed tenure system comprising individual, family, subgroup and larger group rights and duties matching the variety of its products and services (Cousins, 2000, p. 154). The complexity of the tenure regimes may also be exacerbated because many indigenous forests are formally state property, though, in practice, the government may find it challenging to regulate their use. Many of these forests are being 
used and managed by local communities through their customary tenure, although they have no formal rights to do so.

Customary rights to the resources and tenure regimes had been seen as chaotic and often leading to environmental degradation - as described by Hardin in his 'the tragedy of the commons'.In what appears as a paradigm shift, they are now perceived as flexible and facilitating environmental management (Ostrom, 1990; Fitzpatrick, 2005). In many cases, customary land tenure controls land relationships in a way that is more flexible and more adaptable to location conditions than would be possible under a more centralized system. In Ghana, for instance, researchers observe that among other things, logging, shifting cultivation, and more especially land and tree tenure arrangements are critical drivers of deforestation (Appiah et al., 2009). This suggests that issues of tree and forest ownership arrangements, rights and benefit systems and access to forest resources have implications on forest resource use and general sustainable forest management. This paper discusses the concept of land and tree tenure to concerning sustainable forest management. Studies argue that when tenure arrangements bring government-owned forests under the management of local communities, it is likely to enhance effectiveness and efficacy of management while the security of rights is also expected to translate into more direct livelihood benefits from forests to communities (Larson et al., 2010). This study uses both theoretical and empirical literature to examine how land and forest tenure influences sustainable forest management with a view of drawing relevant lessons for policymakers especially in the sustainable development goal era where the emphasis is placed on sustainable forestry. The study is organized into five main sections. Beyond this section, the paper is organized as follows: section two provides a conceptual overview of tenure arrangements; section three presents a brief methodology for the study. The fourth section offers a detailed discussion of how tenure arrangements foster or retards SFM, and a final part deduces useful conclusions and policy recommendations.

\section{Conceptual Overview}

Land tenure is one of the primary governance mechanisms in the community-based approach to conservation. In this context, land tenure can include ownership, user rights and responsibilities, the enforcement of property rights, or all three. Though most forests world over is state-owned, more than one-fourth of forests in developing countries are either owned by or managed by communities (Larson et al., 2010). Tenure reforms have often involved transferring or recognizing the rights of communities occupying forestlands, including indigenous rights, along with responsibilities to protect forests. However, in most cases, the State has retained management rights and control (Larson et al., 2010). As a result, giving communities land tenure rights has simultaneously expanded and restricted their power by, on the one hand, increasing legal rights to forest resources (typically subsistence rights), but, on the other, undermining local institutions with increased state control, monitoring, and regulation. The most effective decentralized Governance has been found to be that which improves both access and exclusion rights, and also decision-making rights (Larson et al., 2010). 


\subsection{Tenure Systems and Ghana Case}

The concept of land tenure, according to Kassanga, (1998), involves the various laws, rules and obligations that structure the holding and ownership rights and interest of land. This explanation is given support by the Food and Agricultural Organization, FAO (2002) which defines tenure systems to entail ownership and user rights to a given resource for a given period with some arrangements and conditions. The idea of land tenure has implications on how trees or forests get protected or degraded.

German et al. (2010) classify the tenure systems in Africa into three primary forms: state property; private property; and common property. Each of these arrangements has implications on how people or stakeholders relate to land or forests; this is because people depend on these for their basic socioeconomic livelihoods. To understand how tenure reforms affect local livelihoods, it is noteworthy to consider de facto access rights of local people that are hinged on tradition or other mechanisms of public recognition (Larson et al., 2010), in addition to de jure rights based on statutory law.

In Ghana, the customary land tenure system involves stool, skin, clan, family and s ownprivate lands. Arko-Adjei et al. (2009) report that approximately seventy-eight (78) per cent of the total land area in the country fall within the ambit of customary landowners. The remaining twenty (20) percents are government or State-owned while a final two (2) per cent is controlled through a dual ownership system that entails legal estates for government and customary authorities. The customary tenure system mostly traditional powers who wield allodial title to such lands in trust for their communities (Kasanga, 1996). It also involves family heads who hold family lands in trust for the members of the family and their generations. Family and individually owned lands get passed on to the succeeding generations through inheritance, which is either matrilineal (this is where the property is passed from the mother's brother to sister's son) or patrilineal (i.e., the property is passed from father to son)

Aside from land tenure systems, Fortmann (1985) reports that distinct tree tenure access rights prevail in the Ghanaian context. During the colonial period, the Forest Service of Ghana appeared more engrossed with a reservation with ownership rights to the tree resources entrusted with traditional leadership (chieftaincy) which were underpinned by customary law (also Parren \& Reitze de Graaf, 1995). However, since 1962 after Republican status, the State held rights over all ancestral tree resources and took over the rights from the traditional communities (Hansen et al., 2009). In other words, trees in the reserves and naturally occurring trees outside the reserves since 1962 became vested in the President in trust for the landowners. It should be noted that landholding regimes have an implication on the tree ownership and management and for that matter, sustainable forest management. The main landholding regimes include; freeholding, customary freeholding, lease holding, and statutory allocations.

* Freehold: this entails the absolute right to control, manage, use and dispose of a piece of land. This is the same as the allodial (totalcomplete ownership) interest for the property that a stool (person or group of persons having control over community and 
family lands in Southern Ghana), a clan, a family, an earth priest or a private person holds. This interest can be transferred from one owner to another (Dadson\& Ebenezer, 2006);

* Customary ' freehold': the rights of a subject or member of a stool/ skin (the equivalent of a stool in Northern Ghana) or family to free use of the land. When analyzing the holdings of such lands under customary law, members who acquire such customary freehold rights pay a token for the rights to use such lands (Larbi, 2009);

* Leasehold': land belonging to one entity and leased to another entity for a fixed period through contractual agreement; and

* 'Statutory allocations': land allocated for the use of some legally constituted body.

\section{Methodological Approach}

This study adopts arguments and observations from existing theoretical and empirical studies to discuss land and tree tenure arrangements in the context of sustainable forest management. In other words, the paper examines the implications of tenure and forest ownership arrangements, including forest access rights on sustainable forest management. The paper adopted secondary materials and sources to assess critical themes and trends in recent empirical studies on the nexus between tenure, ownership and forest access rights on sustainable forest management. The literature search covered all terms and terminologies as approximately related to sustainable forest management: SFM", land tenure and forest sustainability", "land ownership and SFM", "forest access rights and degradation", and "tree, forest regimes and sustainability". The different worlds and the concept of sustainable forests (SFM) were combined variously to obtain a pool of more relevant literature on tenure arrangements and SFM. The following three search engines were predominantly resorted to based on their relevance to the topic area and accessibility to the researcher: Sciencedirect, Tandfonline, and Google Scholar. The large pool of articles from these sources was initially sorted for relevance by skimming through their abstracts. At the end of this initial screening process, irrelevant materials were eliminated, and a shortlist of abstracts for detailed and systematic review was done. The observations from these resources have been used to elicit vitalcritical themes classified in the discussion section of this paper which are adequately examined with the help of empirical observations from recent literature

\section{Discussion}

\subsection{Access, the Security of Access Rights and Forest Protection}

Scholars maintain that most forests and trees get destroyed partly because local people and user groups get alienated from the ownership regime. Scholars observe that in some cases, more secure tenure rights to local people have significantly led to improved forest management (Ricketts et al., 2010). This is because such process increases enforcement of rules and monitoring since the people and their groups are very close to the same forest they derive their basic livelihoods and would not allow others or own people to unduly degrade to the unsustainable stage. This is bolstered by Chhatre and Agrawal (2008) who undertook a systematic review of data from 152 forests across nine different countries whose outcomes 
and conclusions revealed that forest degradation is inversely related to intense collective action and rule enforcement at the local level. This suggests that given access to local people and delineating their unique roles in forest ownership arrangements help reduce collective action, which will encourage effective monitoring and compliance. On his part, Tacconi (2007) maintains that converting forests to other uses will bring more enormous livelihood benefits and may even be 'sustainable' over the long term.

There are, however, others who hold contrary views on this; for instance, Sayer et al. (2008) contend "there is no guarantee that local people will conserve forests if they have more, or more secure, rights, though the central tenet- that secure rights permit longer-term horizons and greater interest in sustainability appears to hold" (p. 13). That regard, existing studies in the Ghanaian context contend that leasehold and sharecrop land holding farming activities contribute to deforestation, which could be explained by the insecurity of tenure associated with such land-holding arrangement, compared to the customary freehold land tenure. According to an FAO Report (2002), this is reached due to some provisions in the statutory books such as Ghana's Concession Act, 1962 (Act 124), which forbids tree felling in the off-reserve and reserve forests for monetary gains (see also Parren \&Reitze de Graaf, 1995). Provisions in same Act proscribes farmers form getting the direct marginal benefits that local communities derive from timber resources on their farmlands. Any other land-holding arrangement that implicitly or explicitly alienates the local people and deprives them of primary benefits is a recipe for deforestation and land degradation. In Ghana, although there is a sharing mechanism for rents from timber trees, such stumpage fees get shared among only some constitutionally delineated recipients, including the particular MMDA, Administrator of the Stool Lands, and the Traditional Council within the territory of the MMDA. The Forestry Commission of Ghana also withholds the largest proportion of the stumpage fees as part of administrative and forest management costs (Hansen et al., 2009) even before giving the residue to the entities mentioned above( Damnyag et al., 2012)

\subsection{Experiences with Tenure Regime Trends in Africa}

Botswana represents a more progressive case, where resources have been gradually transferred from freehold to tribal authorities, with the State maintaining limited areas (Selebalo, 2003; Adams \& Palmer, 2007). Botswana has been alienating its land in favour of communities through elected land boards and to the private sector. By 1998, over $20 \%$ of the land had been transferred, due to influential traditional authorities and customary laws. Botswana, it appears, has succeeded in integrating customary norms and practices with statutory requirement (ITTL, 2003). However, Malawi did the opposite, as communities lost land in favour of public and private landholding categories, and between 1983 and 1990, approximately 104,433 ha had been lost (Mataya et al., 2003). Some countries, e.g. Ghana, Mozambique and Zambia explicitly recognize customary rights. In contrast, other countries, e.g. Ethiopia, Mauritania and Rwanda, do not afford customary rights any legal protection, as all land is state-owned (Schoneveld, 2011). New forests and land legislation in West Africa recognize ownership by the State, individuals, communities and local authorities. The owners of community and private forests have to respect certain restrictions to guarantee protective forest functions. Still, they haven absolute liberty in decision-making, as far as the more 
commercial plantations are concerned. The most significant changes are related to transferring management and utilization rights to local groups.

A report by the GNA (2009), indicts farmers operating under sharecropping and leasehold land tenure system as these individuals resort to farming practices that are not sustainable. Farmers mostly adopt the use of agrochemicals which indirectly terminate growth of seedlings of timber species which could have otherwise redevelop on such farmlands which inadvertently obstruct tree growth. These share crop and lease-holding farmers resort to such practices partly because of their quest to meet the food and income requirements of their households and the possibility of satisfying the conditions imposed on them by the landowners. Therefore, issues about tree regeneration do not fall within their core concerns. The previous demonstrates that land tenure arrangements and tenancy patterns do an influence SFM practices (see also Gyasi, 1997). Gyasi (1997) discusses farming practices of tenant farmers and notes that their practices do not uphold sustainable farming because one third to one half of the food crop is cultivated out of overexploitation of the lands given to them by landowners. The finding of Afikorah-Danquah's (1997) study further confirms this land exploitation by migrant farmers. In the Wenchi district, he finds that because tenant farmers depend on short-term leaseholds involving high tenancy fees, they feel insecure and will engage in short-term exploitation of the land.

\subsection{Land Tenure and Sustainable Practices: Empirical Experiences}

A study by Zhang and Owiredu (2007) sought to compare landholders who have issued larger portions of their lands through outright purchase and leaseholds. The study noted that households with larger tracts of land under leasehold demonstrated the possibility of not resorting to plantation establishment. The outcome of the study brings to the fore the role that tenure insecurity plays in deforestation and the implication for sustainable forest management. The idea is that such arrangements, in the long term, tend to reduce the regenerative capacities of lands and also reduces the possibility of younger trees maturing to become forests or commercial timber.

A study by Pichon (1997) had led to similar conclusions in Ecuador. He observes that the more the security of tenure, the less the deforestation. In other words, if households possess more secure tenure rights and less of a threat of encroachment on their land by outsiders, it leads to more protection practices and the likelihood of engaging in farming practices that would nurture naturally occurring trees into plantations. The idea is, it is more plausible for these farmers to invest in tree planting if they rest assured of secured holdings to their acquired lands. This point has been underscored by Leach and Fairhead (2000) landownerfarmers with secured tenure rights are propelled to engage in sustainable practices which foster SFM because these farmers encourage a variety of forest tree species on their parcels. The authors further contend that even where due to land scarcity leads to a somewhat shorter fallow period, this landowner-farmers do respond adequately in sustainable mindset through fallow enrichment and integration of a several rapidly growing trees into their cropping system. Chen and Innes (2014) discuss the effectiveness of new forest tenure reforms and forestry property markets with a particular emphasis on their impacts on SFM promotion in 
China. Adopting a qualitative approach, the authors argue that tenure improvement that promotes decentralization of forest management to individual farmers fosters poverty reduction. This leads to access to income together with an improved life quality of local people (such as access to new houses, new vehicles, and higher education) which cumulatively shape SFM implementation. The study charges further research to ascertain how community empowerment and poverty contribute to SFM implementation.

\subsection{Issues in Forest Tenure: Practical Challenges}

Although many countries in the developing world have attempted within the past three decades to decentralize forest tenure ostensibly to empower local people, actual practice is quite problematic. For instance, while these reforms on paper seek to maximize local people's tenure security and access rights, improvements in practice have faced severe challenges. These include the implementation of rights, the defence of those rights from the ongoing competition as well as the establishment of the institutions required for exercising those rights and to obtain benefits which are to be distributed equitably.

\subsubsection{Frustrating Community People}

In many respect, although decentralization appears to exist and rights given to forest fringe communities, individuals interested in logging have to participate in highly cumbersome and costly processes to obtain permits and licenses (Larson \& Ribot, 2007). The argument is, local people who may want to engage in legal timber logging tend to be frustrated through centralized cumbersome and bureaucratic procedures which may reduce their enthusiasm to go by that approach. It should also be mentioned that such procedures are similar processes required of logging companies although those for communities however further supplementary rules and mostly enforced in a manner that discriminates against communities (Larson \& Ribot, 2007). For instance, Oyono (2009) reports that to establish community forest in Cameroon, the procedures have been mired with severe complications that such ventures could only be accomplished or adhered to only with far-reaching external support (see also Oyono, 2005). The author notes that a pre-requisite management plan which also takes about two years to get done is far expensive and requires close to US\$55,000 and logging activities are to do through low-impact felling procedures (see even Smith, 2006). What appears discriminatory is that the private companies who operate in delineated concessions are not given such stringent requirements and regulations, they require no management plan and no restrictions on logging procedures (Oyono et al., 2006).

Such frustrations and discriminatory practices occur in many parts of the world where community members and groups tend to be strictly governed and frustrated in their efforts to engage with forest products. For instance, in the Philippines, despite a local group or entity given an approved work plan which indicates the targeted yearly timber volumes to be harvested, the actual volume harvested depends on approval from the Department of Environment and Natural Resources, which issues an annual permit. This is because, without such licenses, the local group or cooperative will not be able to enforce their local harvesting plans. What is more problematic is that such approval processes take quite a more extended period mostly over than six months, which render these local cooperative group with 
sometimes a little less than six months to embark on their harvesting operations. Not very different from the Cameroon situation, the procedure is quite centralized and bureaucratic that such approvals only get issued by the department's central office in Manila, and costly to a tune of 4700 US dollars to acquire. The challenges do not even end there but prevail even after one has gone through such unpleasant bureaucratic tussle. In other words, local people struggle through additional regulations regarding the transportation of timber to the roadside and another to the final market (Dugan \& Pulhin, 2006). Those to issue such permits are also stationed very far away from the forest site, which leads to unnecessary delays for those individuals who engage in the legal timber logging business.

In Nepal, the procedure for local people to access forest products has been structured in such a way that state agencies permeate the entire process with stringent regulations which offer these foresters adequate discretion to interfere with the rights of user groups, even though these local groups may have fulfilled all the formal requirements. For instance, the contract paper which structures forest engagement practice is an operational plan prepared and consented by the district forest officer and the community user group. In doing so, the latter, in most cases, use their discretion and technical power to add provisions beyond what is legally required. Paudel and Banjade, (2008) report how an special provision in the operational plan of Sundari Community Forestry User Group frustrates local people. People need permission from district officer and also to record logs harvested by species; in their interview process, they note a case "a CFUG member who wanted to sell 300 cubic feet of excess timber in the market had to visit the range post (a level of local government) more than 12 times over four months before getting the final approval" (cited in Paudel \& Banjade, 2008)

\subsubsection{Poor Tenure Systems and Deforestation}

In a situation where tenure rights are not delineated, community members and groups, resort to deforestation tendencies. Sjaastad and Bromley (1997) argue that tenure insecurity produces poor incentives for people to invest, thereby encouraging unsustainable forest management practices and deforestation in Sub-Saharan Africa. There are several empirical studies to buttress the argument that insecure land and tree tenure leads to deforestation (Hatcher, 2009; Southgate, 1994; Vansina, 1990). For instance, Vansina (1990) uses the Congo Basin case to demonstrate how forest fringe communities many parts of Africa had depended on the forest for a livelihood without any significant damage to these forests, but upon the advent of agro-industries and mining companies, vast portions of the concessions have seen the degradation of 49.4 million Ha (CBFP, 2006; Djeukam et al., 2013). This conflict over forest ownership and access to resources between local communities and governments continues (Oyono, 2005). Wunder and Verbist (2003) contend that secure tenure has a more positive impact on tree planting and agroforestry processes than on natural forest management. Whichever form it might take, secure rights in one way or the other affects reducing deforestation and empowerment of local people which implies sustainable forest management (see also Arnot et al., 2011).

In their study, McGinley and Cubbage (2012) carry out a comparative evaluation of 
government's regulation of forest to assess the success or failure factors in the drive to SFM in Costa Rica, Guatemala, and Nicaragua. Key observations were that inadequate organizational structures, resources and processes for policy SFM policy enforcement diminished the potentially positive outcomes of regulatory rigour and comprehensiveness. The authors observe "gaps and failures in the timber tracking and judicial systems which adversely affected the effective implementation of government forest policy" (p. 369). In other words, limited penalization of forest-related crimes through the judicial system reduce deterrence for flouting SFM regulations and laws. It was also observed that forest agency autonomy and decentralization of resources and decision-making processes are associated with enhanced forest management policy implementation. The study contends that interventions such as innovative forest policy enforcement, verification processes as well as the active involvement of non-state actors helped to an extent, mitigate the challenges of limited resources.

The combination of complex bureaucracies, high up-front costs in time and money, the lack of credit facility, forest officer interference and the risk associated with demanding formal markets presents major disincentives for community investment informal management plans. Under such conditions, it is implausible that communities will undertake community-based logging operations without significant outside support or other incentives (Pulhin et al., 2010). Forests in developing countries, especially those inhabited by local people, are characterized by interaction and interdependence among the local people (social system) and the forest (ecological systems) and hence engender a Social-Ecological Systems (Hukkine, 2014). The livelihood of local people in these countries is intricately connected to forests (Sunderlin et al., 2005; Mohammed \& Inoue, 2013). For millions of people living in and around these forests, the forest constitutes a dominant part of their physical, material, economic, and spiritual lives (Salafsky \& Wollenberg, 2000; Sunderlin et al., 2005).

\subsection{Community Involvement in Forest Ownership}

Noting the role of people in sustainable forest management, the 1990s have been described as the age of networks which underscores the need to engage and involve local community members and groups meaningfully. That regard, policies associated with land tenure reforms can expedite the knack of local people and groups to act on and engender larger benefits from their new rights. This will be more effective if interspersed with capacity-building activities for local people to optimize their sustainable approach to forests as well as enhancing their access to ready markets. Instead, what prevails is that state agencies and regulations tend to slap these people with burdensome and expensive regulations regarding access to, usage of and making a living out of forest resources. The argument is, instead of stimulating local forest management and building upon effective local rules where these exist, state agencies and foresters mostly rely on strict bureaucratic regulations pillared on fortress timber management.

Despite the strengths associated with local management, secure tenure rights on sustainable forest management (Agrawal, 2007), experience and practice provides mixed results (Blaikie, 2006; Mohammed \& Inoue, 2014; Schusser et al., 2016). This suggests that access and tenure 
rights may not always assure positive social and environmental outcomes (Baynes et al., 2015). For instance, in Indonesia, devolution of powers to community members led to catastrophic aftermath for the forest since local people uncontrollably sought to maximize income from the forest without recourse to forest sustainability tendencies and practices (Larson, 2011). Granting local access and enhancing tenure rights is also at times associated with key challenges which include (i) the knack of local people to remain sordid when their management regime faces with ecological or social changes due to growing complexities (Bremner \& Lu, 2006); (ii) the ability to cope with the influence of powerful individuals (elite capture) within the community (Mohammed \& Inoue, 2012) and (iii) finally ability to be immune from the pressures exerted by dominant private firms which have other stakes (Persha\&Andersson, 2014). Some studies conducted in Asia (e.g. Becker \& León, 2000; Cooke, 2000) indicated that forest conditions were a reflection of ecological and socioeconomic factors. The socioeconomic factors include human population density, markets, resource accessibility and institutional arrangements

\section{Conclusions and Policy Recommendations}

From the discussions above, the study brings to the fore that the idea of tenure rights and tenure security has implications on sustainable forest management. It is therefore prudent to foster a robust tenure regime that upholds local people's access to and usage of forest resources without sinister machinations and subjugation of local people. This is because failure to defend and secure community tenure rights, and the imposition of externally designed rules could result in a debilitating impact on communities and SFM. Clarity and security of ownership and tenure rights is a sine qua non for sustainable forest management. These remain crucial in avoiding and resolving tenure-related conflicts. Determined rights and their long-term security are also necessary for encouraging the title holders to make a profound long-term investment in SFM which would enhance greater forests and trees in the long run. Investment in SFM, in turn, is essential for tapping the potential of forests for providing improved livelihoods, income and employment. In other words, while customary tenure arrangements may sometimes be less than ideal in social, economic or environmental terms, the fact that they are embedded in complex social processes means that any attempt to change or replace them may involve prohibitive costs and risks (Fitzpatrick, 2005). It is crucial to ascertain credible data to institutionalize tenure arrangements through broader stakeholder deliberations which also come with more significant benefit-sharing schemes to incentivize rightsholders as well as individuals and groups. Successful ownership and tenure arrangements that support and promote sustainable forest management depend on a variety of factors which include, among other things, history, culture, traditions, political stability and level of economic development. All forms of arrangements have their strengths and limitations. For example, public access (the practice situation where several groups utilize forests without clear rules, responsibilities, and control) has produced a negative impact on sustainable forest management (SFM) as a result of the tragedy of the commons.

Public ownership and management often seem to be considered mainly when the main goal is to produce public goods, such as environmental services. On the other hand, in many cases, tenure by individuals, households and communities or industry seems to have had a positive 
linkage to production and livelihoods (Toivonen, 2007).

\section{Recommendations and Policy Implications}

From the discussions and conclusions above, the study makes the following recommendations.

Firstly, it is prudent to foster clarity and long-term security of ownership and tenure rights regarding forest products. This is the surest way to get local people and farmers to adopt a sustainable approach to nursing, protecting and managing commercial trees which find their way on their lands. It is prudent to institutionalize measures that provide incentives for local community members or forest fringe communities as efforts for managing and protecting forests and trees. Following from above, it is also essential to enhance proper enforcement of rights and responsibilities and cost-efficient arrangements for rights transfer. Furthermore, there is a need to foster stakeholder participation, especially in the development of management rules which may bind community members and right holders. A proper stakeholder consultation and deliberation activities will ensure rules and regulations are adhered to, and monitoring will not be much expensive as local people themselves will be part of the process.

Additionally, there is a need to promote capacity-building for administrators and rights holders, particularly new rights holders, to adopt a sustainable mindset in their exploitation of timber products. Standard practices of not felling younger tree species and replanting should be a stock in trade of lumbering companies who secure tenure rights from the State. This only comes when these are given proper training through seminars, workshops and symposia.

Moreover, it is crucial to ensure a fair balance between the quest for forest sustainability with the economic wellbeing (profit interests) of owners and tenure holders. This is the surest way to ensure that forest sustainability does not rip off the economic welfare of land and forest right holders. The design of any benefit-sharing scheme for forest resources should not relegate to the background the role and share of the farmers who operate on rented lands, especially the holders of sharecrop. This could be more streamlined if there is an improvement in access to information on forest tenure and ownership. In addition to the above, to ensure local community members adopt prudent management of forest resources, it is also essential to provide these with other livelihood activities through capacity building and to resource them. More importantly, there should be conscious efforts to promote efficient markets and market access for small producers so that it becomes lucrative and sustainable in the long run. These economic activities will help reduce their reliance on the forest.

Finally, it is crucial for law enforcers and foresters to be given adequate resources to streamline their monitoring activities, and other related operations which help to ensure all stakeholders and right holders stick to stipulated principles and practices while illegal loggers are checked and arrested. It is often a case where patrol team may not even get the needed resources at times, including right vehicle, safety gadgets and yet also a shortage of personnel which tend to frustrate effective monitoring. It should be reckoned that private entities who engage in logging activities or flout SFM rules are sophisticated with state-of-the-art 
equipment and the public agencies deployed to check these must be equipped as such otherwise the former will overpower the latter or even be compromised, after all, "if you cannot beat them, just join them".

\section{Reference}

Adams, W. M. (2004). Against extinction: The story of conservation. Earthscan, London.

Afikorah-Danquah, S. (1997). Local Resource Management in the Forest-Savanna Transition Zone: The Case of Wenchi District, Ghana. IDS Bulletin, 28(4), 36-46.

https://doi.org/10.1111/j.1759-5436.1997.mp28004005.x

Agrawal, A., Chhatre, A., \& Hardin, R. (2008). Changing Governance of the world's forests. Science, 320(5882), 1460-1462. https://doi.org/10.1126/science.1155369

Anaya, S. J., \& Grossman, C. (2002). The case of AwasTingni v. Nicaragua: a new step in the international law of indigenous peoples. Arizona Journal of International and Comparative Law, 19(1), 1-15.

Appiah, M., Blay, D., Damnyag, L., Dwomoh, F. K., Pappinen, A., \& Luukkanen, O. (2009). Dependence on forest resources and tropical deforestation in Ghana. Environment, Development and Sustainability, 11(3), 471-487. https://doi.org/10.1007/s10668-007-9125-0

Arko-Adjei, A., De Jong, J., Zevenbergen, J. A., \& Tuladhar, A. M. (2009). Customary land tenure dynamics at peri-urban Ghana: Implications for land administration system modeling. Surveyors Key Role in Accelerated Development. pp. 1-18.

Baynes, J., Herbohn, J., Smith, C., Fisher, R., \& Bray, D. (2015). Key factors which influence the success of community forestry in developing countries. Global Environmental Change, 35, 226-238. https://doi.org/10.1016/j.gloenvcha.2015.09.011

Bremner, J., \& Lu, F. (2006). Common property among indigenous peoples of the Ecuadorian Amazon. Conservation and Society, 4(4), 499.

Campese, J., Sunderland, T. C. H., Greiber, T., \& Oviedo, G. (Eds.). (2009). Rights-based approaches: Exploring issues and opportunities for conservation. Bogor, Indonesia: Center for International Forestry Research (CIFOR) and the International Union for Conservation of Nature (IUCN).

Cousins, B. (2007). More than socially embedded: the distinctive character of communal tenure regimes in South Africa and its implications for land policy. Journal of Agrarian Change, 7(3), 281-315. https://doi.org/10.1111/j.1471-0366.2007.00147.x

Dadson, J., \& Ebenezer, K. (2006, October). Optimizing Land Asset Management in Ghana a Shared Responsibility and recipe for good Governance. In Shaping the Change XXIII FIG Congress, Munich, Germany.

Dixon, J. A., \& Sherman, P. B. (1991). Economics of protected areas: A new look at costs and benefits. Earthscan, London 


\section{Mll Macrothink}

Environmental Management and Sustainable Development

ISSN 2164-7682 2021, Vol. 10, No. 2

Dugan, P., \& Pulhin, J. (2007). Forest harvesting in community-based forest management in the Philippines: simple tools versus complex procedures. A cut for the poor. pp. 38-46.

Fay, C., \& Michon, G. (2003). The contribution of plantation and agroforestry to rural livelihoods: Redressing forestry hegemony - where a forestry regulatory framework is best replaced by an agrarian one. Paper presented at International Conference on Rural Livelihoods, Forests and Biodiversity, Bonn, Germany.

Fitzpatrick, D. (2005). Evolution and chaos in property right systems: the third world tragedy of contested access. Yale LJ, 115, 996. https://doi.org/10.2307/20455644

Fortman, L. (1985). The tree tenure factor in agroforestry with particular reference to Africa. Agroforestry systems, 2(4), 229-251. https://doi.org/10.1007/BF00147036

German, L. A., Ruhweza, A., Mwesigwa, R., \& Kalanzi, C. (2010). Social and environmental footprints of carbon payments: a case study from Uganda. Payments for Environmental Services, Forest Conservation and Climate Change. Livelihoods in the REDD. pp. 160-184. https://doi.org/10.4337/9781849806015.00013

Gyasi, E. A. (1997). Ability to the farming systems to cope and strategies for sustaining farming. In E. A. Gyasi, \& J. I. Uitto (Eds.), Environment, Biodiversity and Agricultural Change in West Africa (pp. 84-89). United Nations University Press, Tokyo.

Hansen, C. P., Lund, J. F., \& Treue, T. (2009). Neither fast, nor easy: he prospect of Reduced Emissions from Deforestation and Degradation (REDD) in Ghana. International Forestry Review, 11(4), 439-455. https://doi.org/10.1505/ifor.11.4.439

Hukkinen, J. I. (2014). Model of the social-ecological system depends on model of the mind: Contrasting information-processing and embodied views of cognition. Ecological economics, 99, 100-109. https://doi.org/10.1016/j.ecolecon.2014.01.017

Kasanga, K. R. (1988). Land tenure and the development dialogue. Occasional Paper 19. Department of Land Economy, University of Cambridge, Granta Editions, Cambridge.

Larbi, W. O. (2008, September). Compulsory land acquisition and compensation in Ghana: Searching for alternative policies and strategies. In Presentation, FIG/FAO/CNG International Seminar on State and Public Sector Land Management, Verona, Italy. [Online] Available: http://www.fao.org/3/ai0899t/i0899t02.pdf.

Larson, A. M. (2011). Forest tenure reform in the age of climate change: Lessons for REDD+. Global Environmental Change, 21(2), 540-549.

https://doi.org/10.1016/j.gloenvcha.2010.11.008

Larson, A. M., \& Ribot, J. C. (2007). The poverty of forestry policy: double standards on an uneven playing field. Sustainability science, 2(2), 189-204.

https://doi.org/10.1007/s11625-007-0030-0

Larson. A. M., Barry, D., \& Dahal, G. R. (2010). Tenure change in the global South. In A. M. Larson, D. Barry, G. R. Dahal \& C. J. P. Colfer (Eds.), Forest for People: Community Rights 
and Forest Tenure Reform (pp. 3-18). Earthscan, London.

Leach, M., \& Fairhead, J. (2000). Challenging neo-Malthusian deforestation analyses in West Africa's dynamic forest landscapes. Population and Development Review, 26(1), 17-43. https://doi.org/10.1111/j.1728-4457.2000.00017.x

Mohammed, A. J., \& Inoue, M. (2012). Explaining disparity in outcome from community-based natural resource management (CBNRM): a case study in Chilimo Forest, Ethiopia. Journal of environmental planning and management, 55(9), 1248-1267.

https://doi.org/10.1080/09640568.2011.640171

Ostrom, E. (1990). Governing the commons. Cambridge University Press, New York. https://doi.org/10.1017/CBO9780511807763

Oyono, P. R. (2005). The foundations of the conflit de langage over land and forests in southern Cameroon.

Oyono, P. R. (2009). New niches of community rights to forests in Cameroon: Tenure reform, decentralization category or something else. International Journal of Social Forestry, 2(1), $1-23$.

Oyono, P. R., Ribot, J. C., \& Larson, A. M. (2006). Green and black gold in rural Cameroon: Natural resources for local justice, Governance and sustainability. Washington, DC: World Resources Institute Working Paper No. 22.

Parren, M. P., \& de Graaf, N. R. (1995). The quest for natural forest management in Ghana, Côte d'Ivoire and Liberia. StichtingTropenbos.

Peluso, N. L. (1992). Rich forests, poor people: Resource control and resistance in Java. University of California Press, Berkeley, California.

https://doi.org/10.1525/california/9780520073777.001.0001

Persha, L., \& Andersson, K. (2014). Elite capture risk and mitigation in decentralized forest governance regimes. Global Environmental Change, 24, 265-276.

https://doi.org/10.1016/j.gloenvcha.2013.12.005

Pichón, F. J. (1997). Colonist land-allocation decisions, land use, and deforestation in the Ecuadorian Amazon frontier. Economic Development and Cultural Change, 45(4), 707-744. https://doi.org/10.1086/452305

Ricketts, T. H., Soares-Filho, B., da Fonseca, G. A., Nepstad, D., Pfaff, A., Petsonk, A., ... Creighton, K. (2010). Indigenous lands, protected areas, and slowing climate change. PLoS biology, 8(3), e1000331. https://doi.org/10.1371/journal.pbio.1000331

Sayer, J., Bullb, G., \& Elliottc, C. (2008). Mediating forest transitions: 'Granddesign' or 'Muddling through'. Conservation and Society, 6(4), 320.

https://doi.org/10.4103/0972-4923.49195

Schusser, C., Krott, M., Movuh, M. C. Y., Logmani, J., Devkota, R. R., Maryudi, A., ... Bach, N. D. (2015). Powerful stakeholders as drivers of community forestry-Results of an 


\section{Macrothink \\ Environmental Management and Sustainable Development \\ ISSN 2164-7682 \\ 2021, Vol. 10, No. 2}

international study. Forest Policy and Economics, 58, 92-101.

https://doi.org/10.1016/j.forpol.2015.05.011

Smith, W. (2006). Regulating timber commodity chains: Timber commodity chains linking Cameroon and Europe. Paper presented at conference of the International Association for the Study of Common Property (IASCP). Bali, Indonesia.

Sunderlin, W. D., Angelsen, A., Belcher, B., Burgers, P., Nasi, R., Santoso, L., \& Wunder, S. (2005). Livelihoods, forests, and conservation in developing countries: an overview. World development, 33(9), 1383-1402. https://doi.org/10.1016/j.worlddev.2004.10.004

Sunderlin, W., Dewi, S., Puntodewo, A., Müller, D., Angelsen, A., \& Epprecht, M. (2008). Why forests are important for global poverty alleviation: a spatial explanation. Ecology and society, 13(2). https://doi.org/10.5751/ES-02590-130224

Tacconi, L. (2007). Decentralization, forests and livelihoods: theory and narrative. Global environmental change, 17(3-4), 338-348. https://doi.org/10.1016/j.gloenvcha.2007.01.002

Zhang, D., \& Owiredu, E. A. (2007). Land tenure, market, and the establishment of forest plantations in Ghana. Forest Policy and Economics, 9(6), 602-610.

https://doi.org/10.1016/j.forpol.2005.12.001

\section{Copyright Disclaimer}

Copyright for this article is retained by the author(s), with first publication rights granted to the journal.

This is an open-access article distributed under the terms and conditions of the Creative Commons Attribution license (http://creativecommons.org/licenses/by/4.0/). 